\title{
PCDD/F EMISSIONS FROM VIRGIN AND TREATED WOOD COMBUSTION
}

\author{
G. PASSAMANI ${ }^{1}$, E.C. RADA ${ }^{2}$, W. TIRLER ${ }^{3}$, M. TAVA ${ }^{4}$, V. TORRETTA ${ }^{1}$ \& M. RAGAZZI ${ }^{2}$ \\ ${ }^{1}$ Insubria University, Biotechnology and Life Science Department, Varese, Italy. \\ ${ }^{2}$ University of Trento, Civil, Environmental and Mechanical Department, Trento, Italy. \\ ${ }^{3}$ Eco-Research, Bolzano, Italy. \\ ${ }^{4}$ Provincial Environmental Protection Agency, Trento, Italy.
}

\begin{abstract}
Energy from biomass is becoming increasingly important as fossil fuel reserves diminish. The utilization of biomass is already prevalent in the domestic heating sector, but produces significant amounts of pollutants that are detrimental to human health. Dioxins, formed in any combustion process where carbon, oxygen and, chlorine are present, are a subject of major interest due to their carcinogenicity. Much research has been carried out to study emissions from hazardous and municipal waste incinerators. Dioxin emission from wood combustion plants are also of interest, especially those due to combustion of treated, varnished or PVC-coated wood, which can produce high polychlorinated dibenzofurans (PCDD/F) emissions. This study compares the PCDD/F emissions produced by burning treated wood and virgin wood to verify if the differences are significant. Six different wood samples were analysed (three of treated wood and three of virgin wood) and a two-step wood gasification boiler was used. The analysis has been conducted both on off gas and on ashes. The measured PCDD/F concentrations are to be considered particularly limited and the treated wood use does not cause a general worsening in the PCDD/F emission. Thus, the wood treatment - subject of study - is not dangerous for PCDD/F. Finally, the experimental results indicated that during the thermal treatment, the formation mechanism of PCDD/F is the de novo synthesis.
\end{abstract}

Keywords: air emissions, ash, biomass, combustion, polychlorinated dibenzofurans, polychlorinated dibenzo-p-dioxins, treated wood.

\section{INTRODUCTION}

Energy resources play an important role in the world's future. Energy is considered a prime agent in the generation of wealth and a significant factor in economic development. The importance of energy in economic development is recognized universally and historical data confirm that there is a strong relationship between the availability of energy and economic activity. There are many alternative new and renewable energy sources that can be used as a substitute for fossil and conventional fuels [1]. Biomass such as wood, bark, straw, and biowaste is a promising $\mathrm{CO}_{2}$-neutral alternative solid fuel owing to the decreasing resources of fossil fuels [2]. Current energy consumption of biomass accounts for about $9.7 \%$ of total world energy consumption, second only to coal, oil, and natural gas [3]. Developing countries account for $75 \%$ of biomass utilization [4]. As of 2009, the energy consumption in Italy was 180 Mtoe (million tons of oil equivalent), where all renewable energy resources, including hydropower and biomass, accounted for 20.7 Mtoe (about 11.7\%) [5]. While no official figures exist as to the contribution of biomass alone, some recent estimates report a total potential of 24-30 Mtoe (about 13.6\%) [6].

Recently it was suggested to use agricultural products (such as poplar from short rotation foresty and miscanthus) and by-products for domestic heating. The opportunity of using agricultural residues as fuel allows the agricultural production to be diversified towards the area of energy production. Domestic combustion of biofuel may be carried out in simple wood stoves as well as in more advanced ones, such as pellet burners and modern wood boilers, and 
the emissions of pollutants may vary over a wide range [7, 8]. However, biomass utilization in thermal energy production is not devoid of problems because of its physical characteristics (e.g. particle size, bulk density, moisture content, ash, gross calorific value) and its chemical composition which are substantially different from conventional energy sources $[9,10]$. It is known that biomass burning in boilers emits pollutants in the atmosphere, the main of which are particulates, carbon monoxide $(\mathrm{CO})$, nitrogen oxides $\left(\mathrm{NO}_{\mathrm{x}}\right)$, sulphur dioxide $\left(\mathrm{SO}_{2}\right)$, unburned hydrocarbons $\left(\mathrm{C}_{\mathrm{x}} \mathrm{H}_{\mathrm{y}}\right)$, polycyclic aromatic hydrocarbons $\left(\mathrm{PAH}_{\mathrm{s}}\right)$, and other organic compounds [11]. As pointed out by Smith [12], the products of incomplete combustion have three major adverse effects: energy loss, impact on human health, and impact on the environment. He estimated that the use of biomass fuels contributed to $1 \%-5 \%$ of all $\mathrm{CH}_{4}$ emissions, $6 \%-14 \%$ of all CO emissions, $8 \%-24 \%$ of all total non-methane organic compounds emissions and thus to $1 \%-3 \%$ of all human induced global warming.

Besides the pollutants emission in the atmosphere, ash content and ash behaviour are also important parameters both for energy reasons and for technical reasons. In particular, the first one influences the calorific value of the biomass and gives raise to problems involving the disposal of the combustion inorganic residue. Ash behaviour has a great impact on the fouling and slagging phenomena that is responsible for reducing the energy efficiency and for causing damage to the internal part of the combustion system [13]. For an assessment of biomass as an energy source, from the environmental point of view, it would be important to assess the extent of the multiple emissions besides ash behaviour.

Dioxin is a general term for a group of chemical compounds consisting of 75 polychlorinated dibenzo-p-dioxins (PCDDs) and 135 polychlorinated dibenzofurans (PCDFs), which are structurally very similar, only differing in the number and spatial arrangement of chlorine atoms in the molecule. These compounds are present as traces in the atmosphere, and 17 of these isomers have been shown to be extremely toxic and mutagenic and linked to the suppression of the human immune system. They tend to bind to organic matter in sediments and soils and to accumulate in the fatty tissues of living organisms. In humans, dioxins have a half-life of about 7 years. Dioxins are persistent, toxic, and bio-accumulative (PTB) chemicals and because they can be transported over long distances from the source of emission, they are also persistent organic pollutants (POPs). Combustion is considered a major source of the emissions of PCDDs and PCDFs. Dioxin production is characteristic of controlled and uncontrolled combustion with strong relevance to health, safety, and environmental issues in using biomass for energy $[14,15]$.

Substantial quantities of low grade wood are produced by forestry. These generally cannot be used in industry, for construction or in the furniture industry. These wastes can, however, be treated through combustion, landspreading, or recycling. The possibilities for treated wood recycling are much more limited, because the wood-protecting agents can easily diffuse in undesirable areas like the interior of the wood or the soil. The production of particleboard from treated wood is also questionable due to the same drawbacks. Similar reasons inhibit the use of treated wood residues in landspreading.

According to the European Emission Inventory [16], wood combustion is at present one of the most important air emission sources of dioxins.

Special attention has been paid to the combustion of wood, since not only natural wood but also wood wastes, treated with different types of glue are being burnt. Large quantities of waste wood are produced annually. A part of the wood emerges from construction activities and house demolition. Wood residues (waste and industrial) often contain various types of contaminants (adhesives, resins, paint, and other surface coatings). Another major source of 
dioxins can be salt-laden wood waste that is burned in power boilers [17], at pulp and paper mills.

It is well known that PCDD/Fs are always formed during wood combustion via precursors like phenols and lignin or via de novo reactions in the presence of particulate carbon and chlorine [18]. When waste wood is burnt, the level of dioxins and furans in the flue gas emissions is significantly lower than that obtained from other sources. Even non-treated wood contains small amounts of chlorine, which means that dioxin emissions can only be minimized, but not eliminated [18]. According to EC regulations regarding the classification of biomass and of waste combustion systems, many biomass residues (e.g. non-dangerous wood residues) will be subject to severe dioxin emission regulation, because a perfect separation of 'clean' wood and 'non-clean' varieties (i.e. from demolition, containing laminates or particleboard) is often impossible at the post-consumer level. This compromises a large part of the potential use of biomass combustors, in particular in small-scale applications. There is some empirical evidence, although not conclusive, that the burning of wood in the presence of chlorine or inorganic chlorides may increase PCDD/Fs formation. Few of these experiments had ruled out contamination of wood fibre by known chlorinated precursors through extraction and chemical analysis. None of the mentioned experiments attempted to determine if PCDD/Fs contaminated the wood fibre prior to conducting the experiment. If the atmosphere serves to widely distribute PCDD/Fs, and if PCDD/Fs can exist in the vapour and particle phases in the ambient air, then trees and other biomass can become reservoirs of PCDD/F contamination by means of particle deposition onto and vapour diffusion into the biomass. Moreover, it is well known that there are biological routes that produce dioxins [19]. As long as these possibilities have not been addressed, and their impacts have not been quantified, experiments in which PCDD/Fs are generated from wood combustion must be interpreted with a certain degree of caution, especially with regard to proving that PCDD/Fs can be formed in nature without human intervention.

The aim of the present paper was to compare experimental data regarding dioxin emissions from treated and virgin wood combustion. The objective was to understand whether differences were significant. The analysis has been conducted both on off gas and on ashes.

\section{MATERIALS AND METHODS}

\subsection{The gasification boiler}

The experimental investigation has been carried on the gasifying wood stove 'Arbola-H' (Viessman Werke GmbH \& Co.), with thermal power between $11.0 \mathrm{~kW}$ and $25.9 \mathrm{~kW}$, Fig. 1 [20].

The stove is divided into three sections. In the upper part, the feedstock is initially dried during the heating up of the system. Then the temperature grows up to the operating temperature $\left(900^{\circ} \mathrm{C}-1000^{\circ} \mathrm{C}\right)$ and the pyrolysis and char oxidation processes take place. The produced gas flows through a grid in the combustion chamber, placed below the previous one, in which two processes take place: firstly, the gas is partially oxidized in sub-stoichiometric conditions by means of the primary air stream; secondly, by means of the secondary air, the effective combustion process takes place. The third section of the stove is just a chamber where ash is collected.

An electrochemical analyser was used to measure the gas composition at the stack, for analysing the flue gas concentrations and combustion data such as $\mathrm{O}_{2}, \mathrm{CO}, \mathrm{NO}$, and $\mathrm{SO}_{2}$. 


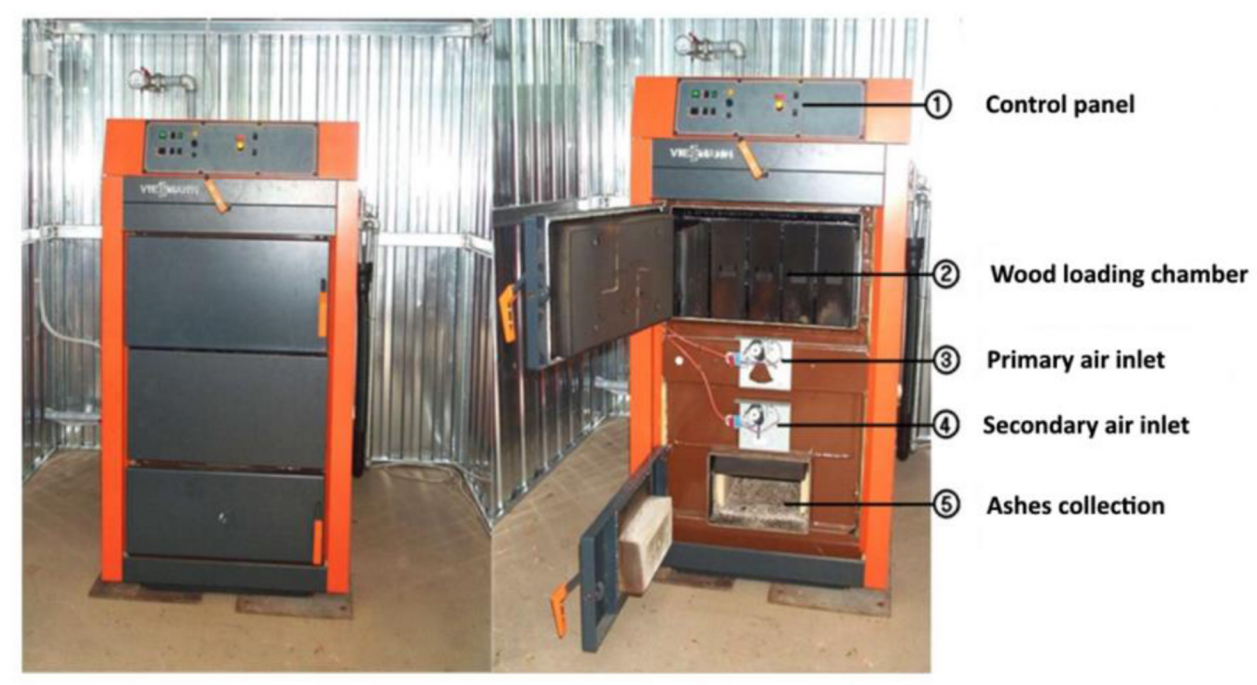

Figure 1: The Viessman 'Arbola-H' gasification boiler used in this study.

Subsequent calculations are made considering the stationary phase of the combustion process. Therefore, no transient phase was considered.

\subsection{Wood samples}

Six combustion tests were carried out: three tests involved virgin wood and three tests involved wood treated with glues, as reported in Table 1. Pictures of the six samples are reported in Figs 2 and 3, for virgin and treated wood, respectively.

\subsection{PCDD/Fs analysis}

PCDD/Fs were monitored in the smoke by a gas sampler (LIFETEK 33 XP-R, Mega System S.r.1.), paired with an automatic processor (ISOCHECK-SRB, Mega System S.r.1.) to perform automatic isokinetic collections with continuous update of the intake flow at the off gas velocity conditions, Fig. 4.

Table 1: Types of wood samples sent to combustion.

\begin{tabular}{ll}
\hline Virgin wood & Treated wood \\
\hline Sample 1: Fir & $\begin{array}{l}\text { Sample 4: Briquettes of fir scraps with traces of vinyl glue } \\
\text { Sample 5: Glued-laminated timber made of fir wood with vinyl glue and } \\
\text { hardener }\end{array}$ \\
$\begin{array}{l}\text { Sample 3: Mixture } \\
\text { fir-larch (80\%-20\%) }\end{array}$ & $\begin{array}{l}\text { Sample 6: Glued-laminated timber made of fir wood with polyure- } \\
\text { thane glue }\end{array}$ \\
\hline
\end{tabular}



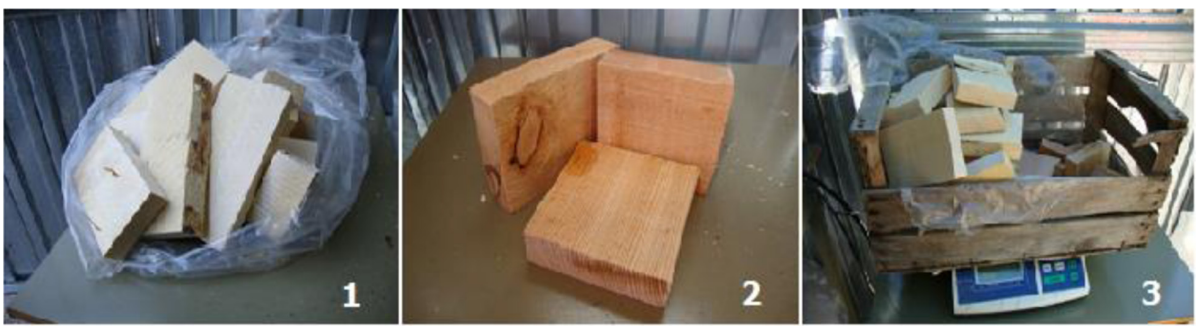

Figure 2: Overview of the samples of virgin wood.
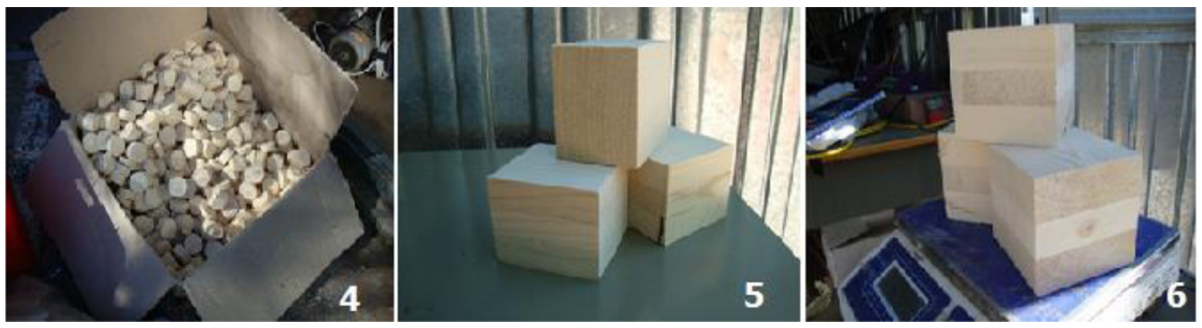

Figure 3: Overview of the samples of treated wood.
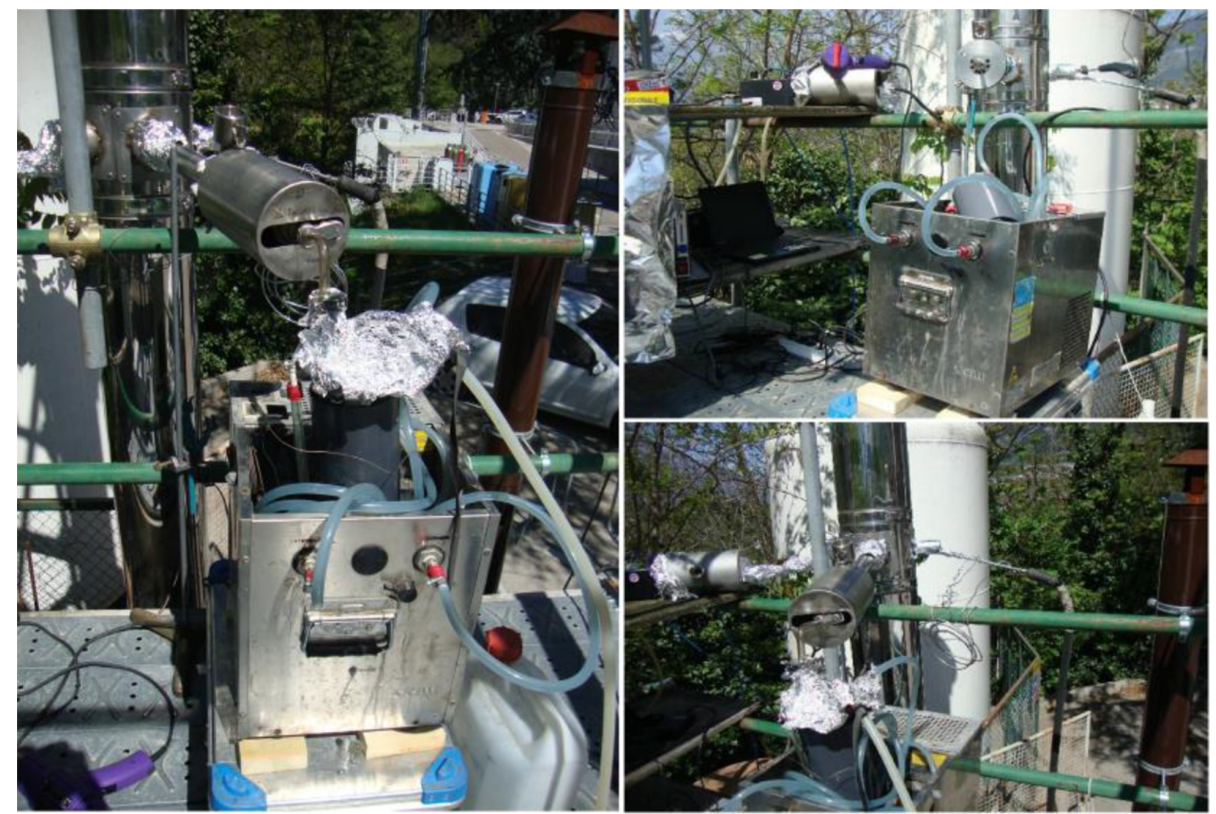

Figure 4: Instrumentation for PCDD/F analysis. 
The instrument has been designed in accordance with standard UNI EN 12919. This feature makes it suitable for the execution of sampling operations that comply with the European directives on occupational health and safety. In fact, it can be used for constant flow rate sampling in indoor/outdoor environments and emission isokinetic sampling. The LIFETEK $33 \mathrm{XP}-\mathrm{R}$ sampler is available with a membrane pump, ensuring high precision in flow regulation over the whole operating range. The high head of the pump, combined with the electronic management and control system, allows to automatically compensate for the fluctuation of the load losses due to filter clogging and to keep the flow rate or the isokinetic flow constant throughout the sampling period.

\subsection{De novo synthesis or precursors formation}

Huang et al. [21] reviewed more studies regarding the formation mechanisms of PCDD/F and concluded that the 'de novo synthesis' can produce PCDD/Fs with the characteristic of 'PCDFs/PCDDs ratio $>1$ ', while the 'precursor formation' produce PCDD/Fs with 'PCDFs/ PCDDs ratio $<<1$ '.

\section{RESULTS AND DISCUSSION}

The presence of PCDD and PCDF in off gas and ashes was monitored. The term 'dioxins' refers to 75 congeners of PCDD and 135 congeners of PCDF. Amongst these $210 \mathrm{com}$ pounds, 17 congeners were analysed because they are considered to be of toxicological concern. These 17 congeners are toxic to many laboratory animals, exposed to chemical, biological, and physical attack, and thus accumulate in the environment, and in organisms such as animals and humans. The Toxic Equivalents (TEQ) method was used for a better comparison and to have toxicity information about the mixture. Within the TEQ method, each dioxin compound is assigned a Toxic Equivalency Factor (TEF). This factor denotes a given dioxin compound's toxicity relative to tetrachlorodibenzo-p-dioxin (TCDD), which is assigned the maximum toxicity designation of one. Other dioxin compounds are given equal or lower numbers, with each number roughly proportional to its toxicity relative to TCDD.

Figure 5 shows the distribution of dioxins and furans congeners in the off gases, for all the analysed wood samples. The concentrations are expressed in terms of percentage (\%) and in the form of Toxic Equivalency (pg I-TEQ/ $/ \mathrm{Nm}^{3}$ ).

Figure 6 shows the concentrations of dioxins and furans from the ash samples collected from the residual and unburned material extraction point. The samples collection was carried out after the necessary cooling of the boiler.

Figures 7 and 8 show, respectively, the summary of the distribution of PCDD/F congeners in the off gases and in the ashes of the six combustion tests. It can be observed that the results of virgin fir and virgin larch are similar, while larch-fir mix has been shown to give different results, compared with those of single materials.

A review of the relationship between PCDFs and PCDDs (Tables 2 and 3), finally, revealed a de novo synthesis formation. 


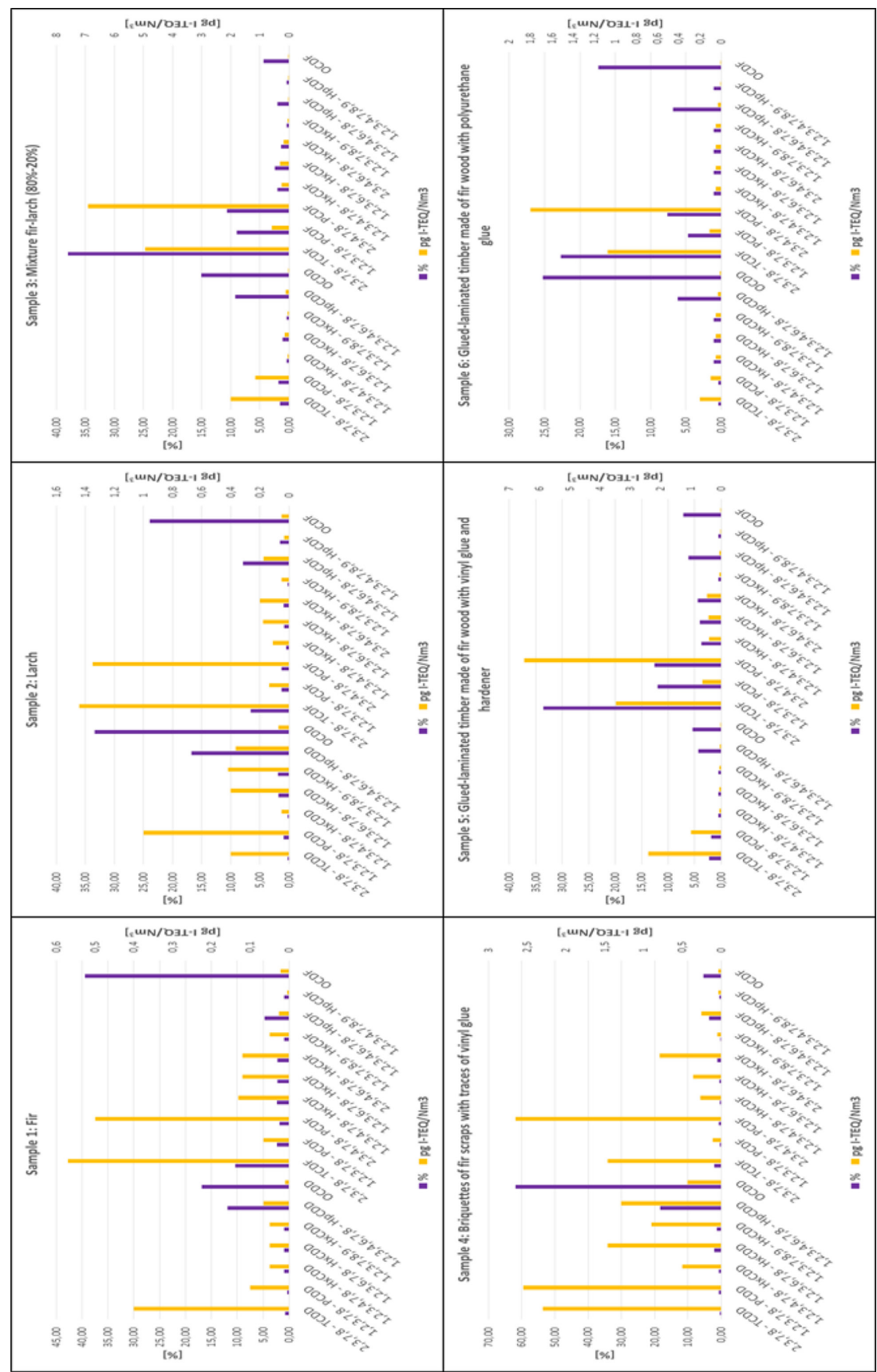

Figure 5: Distribution of dioxins and furans congeners in the off gases of the six combustion tests. 


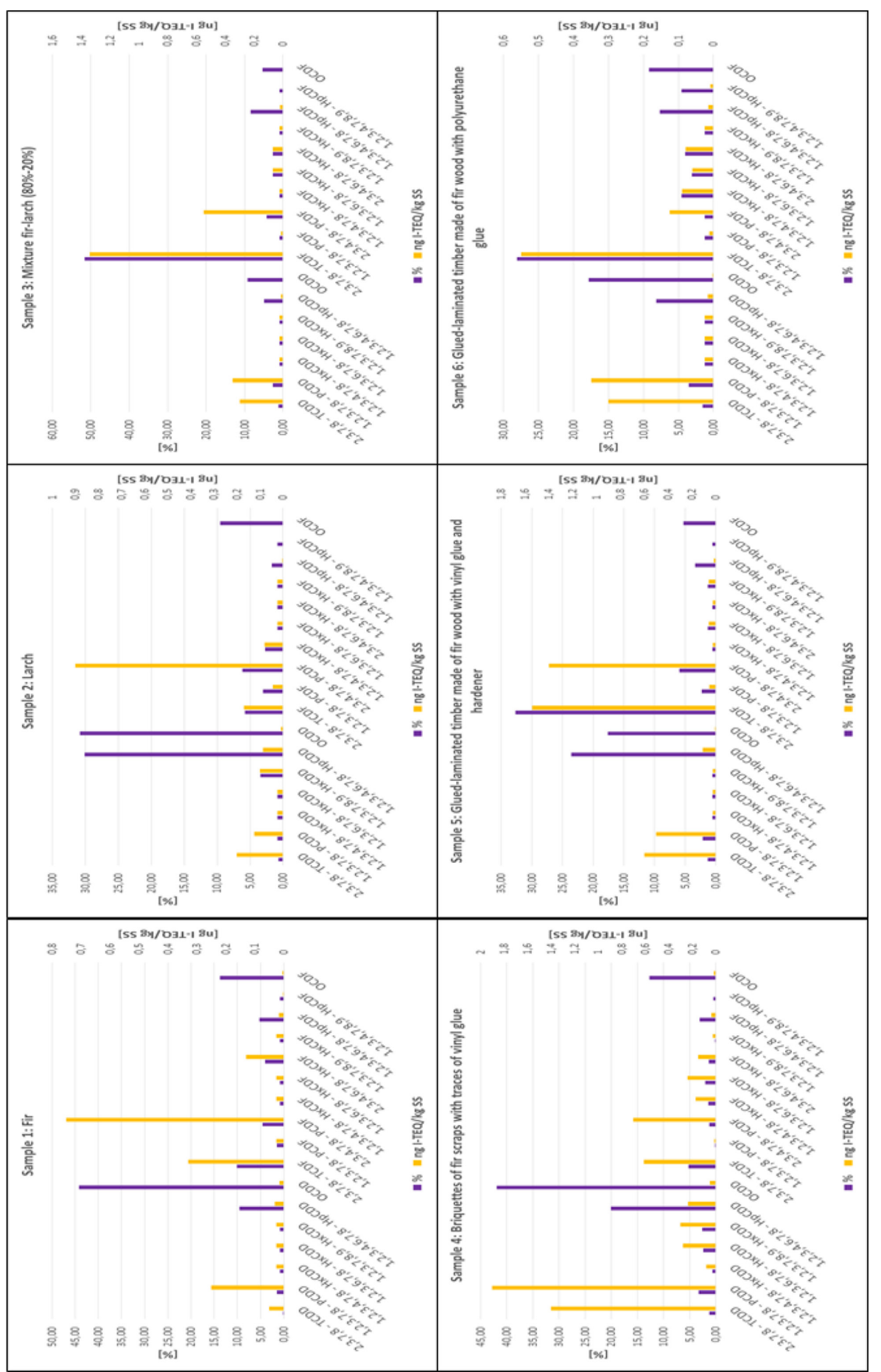

Figure 6: Distribution of dioxins and furans congeners in the ashes of the six combustion tests. 


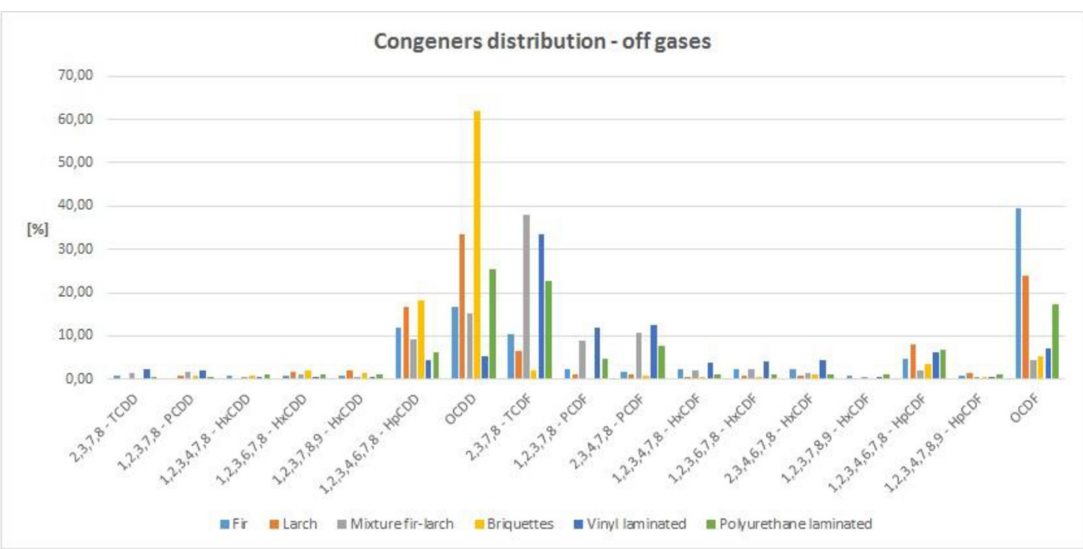

Figure 7: Distribution of PCDD/F congeners in the off gases.

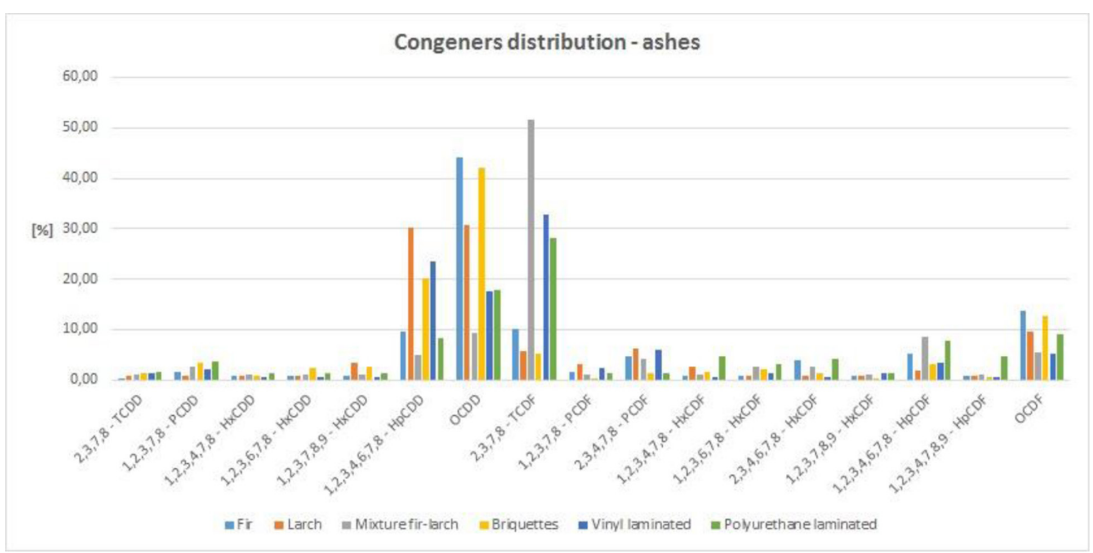

Figure 8: Distribution of PCDD/F congeners in the ashes.

Table 2: PCDFs/PCDDs ratio in the off gases of the six combustion tests.

\begin{tabular}{lllllll}
\hline & $\begin{array}{l}\text { Fir } \\
{\left[\mathrm{pg} / \mathrm{Nm}^{3}\right]}\end{array}$ & $\begin{array}{l}\text { Larch } \\
{\left[\mathrm{pg} / \mathrm{Nm}^{3}\right]}\end{array}$ & $\begin{array}{l}\text { Mixture } \\
\text { fir-larch } \\
{\left[\mathrm{pg} / \mathrm{Nm}^{3}\right]}\end{array}$ & $\begin{array}{l}\text { Briquettes } \\
{\left[\mathrm{pg} / \mathrm{Nm}^{3}\right]}\end{array}$ & $\begin{array}{l}\text { Vinyl } \\
\text { laminated } \\
{\left[\mathrm{pg} / \mathrm{Nm}^{3}\right]}\end{array}$ & $\begin{array}{l}\text { Polyurethane } \\
\text { laminated } \\
{\left[\mathrm{pg} / \mathrm{Nm}^{3}\right]}\end{array}$ \\
\hline Total PCDD & 17.8 & 121 & 38.3 & 601 & 16 & 16.7 \\
Total PCDF & 36.9 & 98.4 & 91.7 & 104.1 & 87.7 & 30.4 \\
PCDF/PCDD & 2.1 & 0.8 & 2.4 & 0.2 & 5.5 & 1.8 \\
\hline
\end{tabular}

Table 3: PCDFs/PCDDs ratio in the ashes of the six combustion tests.

\begin{tabular}{lllllll}
\hline & $\begin{array}{l}\text { Fir } \\
{\left[\mathrm{ng} / \mathrm{kg}_{\mathrm{DM}}\right]}\end{array}$ & $\begin{array}{l}\text { Larch } \\
{\left[\mathrm{ng} / \mathrm{kg}_{\mathrm{DM}}\right]}\end{array}$ & $\begin{array}{l}\text { Mixture } \\
\text { fir-larch } \\
{\left[\mathrm{ng} / \mathrm{kg}_{\mathrm{DM}}\right]}\end{array}$ & $\begin{array}{l}\text { Briquettes } \\
{\left[\mathrm{ng} / \mathrm{kg}_{\mathrm{DM}}\right]}\end{array}$ & $\begin{array}{l}\text { Vinyl } \\
\text { laminated } \\
{\left[\mathrm{ng} / \mathrm{kg}_{\mathrm{DM}}\right]}\end{array}$ & $\begin{array}{l}\text { Polyurethane } \\
\text { laminated } \\
{\left[\mathrm{ng} / \mathrm{kg}_{\mathrm{DM}}\right]}\end{array}$ \\
\hline Total PCDD & 18.8 & 19.8 & 5.5 & 84.1 & 21.8 & 6.9 \\
Total PCDF & 13.8 & 9.5 & 20.5 & 32.5 & 25.4 & 12.8 \\
PCDF/PCDD & 0.7 & 0.5 & 3.7 & 0.4 & 1.2 & 1.9 \\
\hline
\end{tabular}




\section{CONCLUSIONS}

Given the total equivalent toxicity of the six tests, it shows that the recorded values are significantly lower than $0.1 \mathrm{ng} \mathrm{I}-\mathrm{TEQ} / \mathrm{Nm}^{3}$, a limit of the applicable national low on waste incinerators. This limit is usable, to a first approximation, as parameters of comparison, also taking into consideration the different hours of samples.

Furthermore, the use of treated wood does not seem to lead a general worsening in the $\mathrm{PCDD} / \mathrm{F}$ emissions.

The recorded PCDD/F concentrations shall be considered as particularly limited: they are two orders of magnitude below the results of some research on the combustion of natural wood or of wood with a low chlorine or metals level [22, 23]. In particular, the combustion of waste wood treated with organochlorine compounds can produce concentrations three orders of magnitude greater than those observed in this case study. The treatment of the studied wood types, therefore, is not critical for PCDD/F emissions.

In spite of the similarity between total $\mathrm{PCDD} / \mathrm{F}$ concentrations with virgin wood and treated wood as fuel, a complete analysis should not exclude the quantification of the single PCDDs/PCDFs present in the mixtures, since the abundance of some PCDDs/PCDFs, with respect to others, can translate into toxicity levels of the outgoing mixture. In conclusion, additional research in this field is surely recommended.

\section{REFERENCES}

[1] Demirbas, A., Potential applications of renewable energy sources, biomass combustion problems in boiler power systems and combustion related environmental issues. Progress in Energy and Combustion Science, 31(2), pp. 171-192, 2005. http://dx.doi.org/10.1016/j.pecs.2005.02.002

[2] Zhou, H., Jensen, A.D., Glarborg, P. \& Kavaliauskas, A., Formation and reduction of nitric oxide in fixed-bed combustion of straw. Fuel, 85(5-6), pp. 705-716, 2006. http://dx.doi.org/10.1016/j.fuel.2005.08.038

[3] ENEA, Agenzia Nazionale per le Nuove Tecnologie, l'Energia e lo Sviluppo Economico Sostenibile. Ricerca e innovazione per un futuro low carbon, ENEA, 2010.

[4] Zhao, W., Li, Z., Wang, D., Zhu, Q., Sun, R., Meng, B. \& Zhao, G., Combustion characteristics of different parts of corn straw and NO formation in a fixed bed. Bioresource Technology, 99(8), pp. 2956-2963, 2008. http://dx.doi.org/10.1016/j.biortech.2007.06.030

[5] ENEA, Agenzia Nazionale per le Nuove Tecnologie, l'Energia e lo Sviluppo Economico Sostenibile. Rapporto Energia e Ambiente, ENEA, 2007-2008.

[6] ITABIA, Ministero dell'Ambiente e della Tutela del Territorio e del Mare. I traguardi delle bioenergie in Italia, 2008.

[7] Johansson, L.S., Leckner, B., Gustavsson, L., Cooper, D., Tullin, C. \& Potter, A., Emission characteristics of modern and old-type residential boilers fired with wood logs and wood pellets. Environment, 38(25), pp. 4183-4195, 2004.

http://dx.doi.org/10.1016/j.atmosenv.2004.04.020

[8] Dell'Antonia, D., Gubiani, R., Maroncelli, D. \& Pergher, G., Gaseous emissions from fossil fuels and biomass combustion in small heating appliances. Journal of Agricoltural Engineering, 4, pp. 1-10, 2010.

[9] Khan, A.A., Ahob, M., De Jonga, W., Vainikkab, P., Jansensa, P.J. \& Spliethoffc, H., Scale-up study on combustibility and emission formation with two biomass fuels (B quality wood and pepper plant residue) under BFB conditions. Biomass and Bioenergy, 32(12), pp. 1311-1321, 2008.

http://dx.doi.org/10.1016/j.biombioe.2008.03.011 
[10] Obernberger, I., Brunner, T. \& Barnthaler, G., Chemical properties of solid biofuels significance and impact. Biomass and Bioenergy, 30(11), pp. 973-982, 2006. http://dx.doi.org/10.1016/j.biombioe.2006.06.011

[11] Bhattacharya, S.C., Abdul Salam, P. \& Sharma, M., Emissions from biomass energy use in some selected Asian Countries. Energy, 25(2), pp. 169-188, 2000. http://dx.doi.org/10.1016/S0360-5442(99)00065-1

[12] Smith, K.R., Health, energy, and greenhouse-gas impacts of biomass combustion in household stoves. Energy for Sustainable Development, 1(4), pp. 23-29, 1994. http://dx.doi.org/10.1016/S0973-0826(08)60067-8

[13] Toscano, G., Riva, G., Foppa Pedretti, E. \& Corinaldesi, F., Evaluation of solid biomass for energy use in relation to the ash qualitative and quantitative characteristics. Proceeding of AgEng2008 International Conference on Agricultural Engineering \& Industry Exhibition, Creta, 2008.

[14] Schiavon, M., Torretta, V., Rada, E.C. \& Ragazzi, M., State of the art and advances in the impact assessment of dioxins and dioxin-like compounds. Environmental Monitoring and Assessment, 188(1), pp. 1-20, 2016.

http://dx.doi.org/10.1007/s10661-015-5079-0

[15] Schiavon, M., Ragazzi, M. \& Rada, E.C., A proposal for a diet-based local PCDD/F deposition limit. Chemosphere, 93(8), pp. 1639-1645, 2013.

http://dx.doi.org/10.1016/j.chemosphere.2013.08.041

[16] Quaß, U., Fermann, M.W. \& Bröker, G., Steps towards a European dioxin emission inventory. Chemosphere, 40(9-11), pp. 1125-1129, 2000.

http://dx.doi.org/10.1016/S0045-6535(99)00361-6

[17] Luthe, C., Rchardson, B., Easton, C., Kilback, A. \& Strecheniuk, B., Dioxins from mill combustion processes: minimizing their impact of effluent discharges. Pulp \& Paper Canada, 95(12), pp. 481-487, 1994.

[18] Salthammer, T., Klipp, H., Peek, R.D. \& Marutzky, R., Formation of polychlorinated dibenzo-p-dioxins (PCDD) and polychlorinated dibenzofurans (PCDF) during the combustion of impregnated wood. Chemosphere, 30(11), pp. 2051-2060, 1995. http://dx.doi.org/10.1016/0045-6535(95)00083-K

[19] Gadomski, D., Golden, E., Irvine, R.L., Talley, J.W. \& Hundal, L.S., Natural formation of dioxins: a review of trends among four sites. Organohalogen Compounds, 59, pp. 263-266, 2002.

[20] Stefani, P., Antognoni, S., Pieratti, E., Baggio, P. \& Zanoni, S., Efficiency assessment of a domestic wood gasification boiler. UPB Scientific Bulletin, Series D, 77(3), pp. 181-192, 2015.

[21] Huang, H. \& Buekens, A., On the mechanisms of dioxin formation in combustion processes. Chemosphere, 31(9), pp. 4099-4117, 1995.

http://dx.doi.org/10.1016/0045-6535(95)80011-9

[22] Lavric, E.D., Konnov, A.A. \& De Ruyck, J., Dioxin levels in wood combustion - a review. Biomass Bioenergy, 26(2), pp. 115-145, 2004. http://dx.doi.org/10.1016/S0961-9534(03)00104-1

[23] Tame, N.W., Dlugogorski, B.Z. \& Kennedy, E.M., Formation of dioxins and furans during combustion of treated wood. Progress in Energy and Combustion Science, 33(4), pp. 384-408, 2007.

http://dx.doi.org/10.1016/j.pecs.2007.01.001 